\title{
Kesan Penambahan Limonena terhadap Mikroemulsi Asid oleik/Cremophor $r$ 40/Transcutol/Air
}

(Effect of Limonene on the Oleic acid/Cremophor rh 40/Transcutol/Water Microemulsion)

\author{
ZAINUDDin, N., AhMAD, I., AbDUl RAHMAN, I. \& RAMLI, S.*
}

\begin{abstract}
ABSTRAK
Gambar rajah fasa pseudo-ternari sistem mikroemulsi asid oleik/Cremophor rh 40/Transcutol/Air diperoleh melalui pentitratan air pada nisbah surfaktan:kosurfaktan $(\mathrm{Km})$ yang berbeza. Nisbah optimum bagi surfaktan/kosurfaktan adalah Km=2:1. Kesan penambahan limonena sebagai fasa minyak campuran terhadap sistem mikroemulsi diuji pada nisbah limonena:asid oleik (1:1,2:1 dan 3:1). Penambahan limonena berupaya menghasilkan rantau mikroemulsi yang lebih besar sehingga 70\%-80 \% bt. air bagi kesemua nisbah limonena:asid oleik. Nisbah limonena:asid oleik (1:1) memberikan rantau mikroemulsi yang paling luas pada nisbah minyak:surfaktan/kosurfaktan (Minyak:S/KoS=1:9). Sifat isotropik mikroemulsi ditentukan dengan menggunakan mikroskopi cahaya polarasi. Mikroemulsi dibangunkan pada nisbah Km=2:1 dan Minyak:S/KoS (1:9) serta limonena:asid oleik (1:1). Kestabilan dan saiz partikel bagi sistem dikaji dan penambahan limonena didapati tidak merubah sifat serta mikro-struktur sistem mikroemulsi. Kajian konduktiviti elektrik dan kelikatan sistem menunjukkan pembentukan mikroemulsi jenis air-dalam-minyak (10\% dan $20 \%$ bt. air) dan dwiselanjar (30\%-50 \% bt. air). Kesemua sistem mempunyai potensi sebagai sistem penghantar bahan aktif dan menunjukkan kestabilan yang baik pada suhu 4, 25 dan $37^{\circ} \mathrm{C}$ dalam tempoh lebih daripada 6 bulan.
\end{abstract}

Kata kunci: Fasa mikroemulsi; gambar rajah fasa; limonena; mikroemuls; penghantar bahan aktif

ABSTRACT

The pseudo-ternary phase diagram of oleic acid/cremophor rh 40/transcutol/water was prepared along the water dilution line at different ratio of surfactant to cosurfactant $(\mathrm{Km})$. The optimum ratio of surfactant to surfactant was $\mathrm{Km}=2: 1$. The effect of addition limonene as a mixed oils phase on the system were done with the ratio of oleic acid to limonene at 1:1, 1:2 and 1:3. Addition of limonene is able to form stable microemulsions up to 70-80 wt. \% water content for all ratios of oleic acid to limonene. The ratio of limonene:oleic acid (1:1) resulted on the largest microemulsion region was obtained at the ratio of oil:surfactant/cosurfactant (Oil:S/CoS=1:9). The isotropic properties of microemulsion phases were confirmed by polarized light microscopy. Both systems were prepared at Km=2:1 and 1:9(oil:S/CoS) as well as 1:1 (limonene:oleic acid). The stability and particle size study was performed for both systems and its show that the addition of limonene does not change the properties and microstructure of the system. Electrical conductivity and viscosity study of the systems reveals that transformation from water-in-oil microemulsion (10\% and $20 \mathrm{wt} . \%$ water) and bicontinuous microemulsion (30\% to $50 \mathrm{wt}$. \% water). All microemulsions prepared may have potentials as a drug delivery system and show high stability for over 6 months at 4, 25 and $37^{\circ} \mathrm{C}$.

Keywords: Drug delivery; limonene; microemulsion; microemulsion phase; phase diagram

\section{PENGenalan}

Mikroemulsi merupakan sistem yang terdiri daripada air, minyak dan surfaktan. Mikroemulsi terbukti berpotensi bertindak sebagai sistem penghantar bagi pelbagai kaedah seperti oral, suntikan, topikal dan transdermal (Anjana et al. 2012; Fanun 2012; Grampurohit et al. 2011). Sistem mikroemulsi mempunyai kelebihan berbanding sistem konvensional yang sedia ada dari segi pembentukan yang spontan tanpa memerlukan tenaga yang tinggi, stabil secara termodinamik dan berupaya memperbaiki sifat keterlarutan serta bioketersediaan bahan aktif (Idress et al. 2011; Talegaonkar et al. 2008). Penggunaan sistem mikroemulsi sebagai sistem penghantar melalui kulit telah banyak dibangunkan oleh kerana kelebihan sistem ini di dalam meningkatkan penembusan bahan aktif hidrofobik dan hidrofilik melalui lapisan kulit (Al Abood et al. 2013; Maura et al. 2014; Silva et al. 2013; Sintov 2015; Talegaonkar et al. 2008). Komponen amfifilik di dalam sistem mikroemulsi berperanan sebagai bahan penggalak penembusan bagi sistem ini (Idress et al. 2011; Som et al. 2012). Selain itu, penggunaan bahan penggalak penembusan merupakan kaedah yang kian popular untuk meningkatkan penembusan bahan aktif (Williams \& Barry 2004). Asid oleik dan limonena merupakan bahan penggalak penembusan semula jadi (Liu et al. 2011; Singh \& Vijaykumar 2013; Singla et al. 2011). Surfaktan dan 
kosurfaktan yang digunakan di dalam aplikasi farmaseutik seharusnya tidak memberikan kesan toksik dan iritasi kepada pengguna. Surfaktan jenis tidak berionik adalah selamat digunakan bagi aplikasi ini, dengan tolerasi yang baik terhadap penghantaran melalui kulit (Grampurohit et al. 2011).

Pembentukan sistem mikroemulsi umumnya dipengaruhi oleh jenis dan struktur fasa minyak dan surfaktan/kosurfaktan. Faktor seperti nisbah surfaktan:kosurfaktan (S/KoS), panjang rantai kosurfaktan dan jenis rantai hidrokarbon fasa minyak dilaporkan mempengaruhi pembentukan mikroemulsi (Basheer et al. 2013; Sripriya et al. 2007). Contohnya, panjang rantai fasa minyak perlu sesuai dan mudah berinteraksi dengan panjang rantai surfaktan (Sripriya et al. 2007). Fasa minyak-air distabilkan apabila molekul surfaktan berupaya menyusun dengan membentuk lapisan filem yang mengurangkan tegangan permukaan seterusnya mendorong percampuran minyak dan air (Basheer et al. 2013; Sripriya et al.2007). Penambahan kosurfaktan dalam penyediaan mikroemulsi adalah perlu untuk mengurangkan ketegangan fasa minyak-air, seterusnya meningkatkan pembentukan sistem mikroemulsi (Basheer et al. 2013).

Penyelidikan ini adalah bertujuan untuk mengkaji penambahan limonena terhadap sistem mikroemulsi berasaskan asid oleik (AO) sebagai fasa minyak, cremophor rh 40 (CRH40) sebagai surfaktan dan transcutol (TC) sebagai kosurktan bagi aplikasi penghantaran bahan aktif melalui lapisan kulit. Kesan penambahan limonena (L) sebagai fasa minyak dilihat daripada fasa dan sifat fizikal sistem mikroemulsi. Limonena merupakan sebatian minyak pati terpena siklik. Rasionalnya, sejarah sains telah melaporkan penggunaan minyak pati dalam penyediaan mikroemulsi kerana minyak pati mempunyai peranan yang penting dalam bidang farmaseutik (Fanun 2010; Liu et al. 2011). Limonena berupaya meningkatkan pembentukan sistem mikroemulsi serta bertindak sebagai bahan penggalak penembusan semula jadi bagi penghantaran bahan aktif hidrofobik dan hidrofilik (Liu et al. 2011; Sintov 2015). Kesemua komponen sistem mikroemulsi yang dipilih adalah selamat dan tidak mendatangkan kesan sampingan dalam aplikasi farmaseutik, kosmetik dan makanan (Patel et al. 2013; Sarkar \& Hardenia 2011; Shahzadi et al. 2014).

\section{BAHAN KIMIA \& KAEDAH}

Asid oleik dan limonena dibekalkan oleh Merck, manakala cremophor rh 40 'Polyoxyl 40 hydrogenated castor oil' dan Transcutol 'Diethylene glycol monoethyl ether' dibekalkan oleh Sigma-Aldrich. Air suling digunakan sepanjang penyediaan sistem mikroemulsi.

\section{GAMBAR RAJAH FASA PSEUDO-TERNARI DAN PENYEDIAAN SISTEM MIKROEMULSI}

Gambar rajah fasa pseudo-ternari dan penyediaan sistem mikroemulsi dilakukan dengan menggunakan kaedah pentitratan air pada suhu $25^{\circ} \mathrm{C}$ dengan nisbah $\mathrm{Km}$ 1:1, 2:1 dan 3:1 (Cremophor rh 40/Transcutol) serta nisbah fasa minyak limonena/asid oleik 1:1, 2:1 dan 3:1. Nisbah fasa minyak kepada surfaktan/kosurfaktan (minyak:S/KoS) yang diuji adalah 1:9, 2:8, 3:7, 4:6, 5:5, 6:4, 7:3, 8:2 dan 9:1. Air suling ditambah ke dalam campuran minyak/ surfaktan/kosurfaktan dengan peningkatan daripada 5 hingga $95 \%$ bt. Campuran dihomogenkan dengan menggunakan pengacau vorteks selama $5 \mathrm{~min}$. Larutan tersebut dibiarkan pada suhu bilik selama 48 jam untuk menentukan sama ada sistem tersebut mikroemulsi, emulsi atau gel. Larutan yang kekal jernih dan stabil selepas 48 jam dilihat di bawah mikroskopi cahaya polarasi untuk menentukan sifat isotropik sistem yang diperoleh.

\section{SAIZ PARTIKEL DAN KESTABILAN SISTEM MIKROEMULSI}

Purata saiz partikel sistem mikroemulsi ditentukan dengan menggunakan penganalisis saiz partikel (Zeta-Sizer Malvern Instrument, Jerman) sebanyak 3 eksperimen pada suhu $25 \pm 0.1^{\circ} \mathrm{C}$. Kestabilan sistem mikroemulsi diuji dengan menyimpan di bawah suhu 4,25 dan $37^{\circ} \mathrm{C}$ selama sebulan tanpa pendedahan terhadap sebarang pencahayaan (Suria et al. 2015, 2009).

\section{KONDUKTIVITI ELEKTRIK SISTEM MIKROEMULSI}

Konduktiviti sistem mikroemulsi diuji dengan menggunakan konduktometer (Metler Toledo, USA). Pengukuran ditentukan daripada 3 eksperimen pada $25.0 \pm 0.2^{\circ} \mathrm{C}$. Larutan $1.0 \mathrm{mM}$ natrium klorida $(\mathrm{NaCl})$ digunakan bagi menggantikan air suling sebagai sumber elektrolit sewaktu ujian konduktiviti dijalankan. Penambahan larutan natrium klorida tidak merubah sifat fasa dan kejernihan larutan mikroemulsi. Sensor konduktiviti dikalibrasi dengan menggunakan larutan piawai $\mathrm{KCl}(80 \mu \mathrm{S} / \mathrm{cm})$.

\section{KELIKATAN SISTEM MIKROEMULSI}

Kelikatan sistem mikroemulsi ditentukan dengan menggunakan reometer jenis 'cone \& plate' (Anton Paar MC301). Sebanyak $1 \mathrm{~mL}$ mikroemulsi digunakan untuk setiap pengukuran kelikatan sistem pada suhu $25 \pm 0.1^{\circ} \mathrm{C}$. Pengukuran ini dilakukan sebanyak 3 replikasi.

\section{KEPUTUSAN DAN PERBINCANGAN}

Fasa isotropik sistem mikroemulsi samada fasa lamellar isotropik atau cecair kristal ditentukan dengan menggunakan kaedah mikroskopi cahaya polarasi. Sistem mikroemulsi menunjukkan gambaran gelap (tiada dwibiasan) di bawah mikroskopi, manakala sistem bukan mikroemulsi menunjukkan dwibiasan disebabkan oleh strukturnya yang anisotropik (Basheer et al. 2013). Sifat fasa isotropik sistem mikroemulsi berasaskan-asid oleik dan berasaskan-asid oleik/limonena yang diuji di bawah mikroskopi cahaya terkutub. Mikroemulsi berasaskanasid oleik tidak menghasilkan dwibiasan di bawah mikroskopi cahaya polarasi. Di samping itu, penambahan 
limonena juga tidak memberikan sebarang perubahan bagi mikroemulsi yang terbentuk. Mikroemulsi dengan penambahan limonena turut menghasilkan sistem dengan fasa isotropik tanpa dwibiasan.

Jadual 1 menunjukkan senarai mikroemulsi yang terdiri daripada sistem-asid oleik (M1) dan sistemasid oleik/limonena (M2) dihasilkan pada nisbah 1:9 (minyak:S/KoS), Km = 2:1 dan 1:1 (L/AO). Penyediaan mikroemulsi dihasilkan pada kandungan air pada 10, 20, 30,40 dan $50 \%$ bt.

JADUAL 1. Formulasi sistem mikroemulsi

\begin{tabular}{cl}
\hline Formulasi & \multicolumn{1}{c}{ Komponen } \\
\hline M1 & Asid oleik/cremophor rh 40/transcutol/air \\
M2 & $\begin{array}{l}\text { Asid oleik/limonena/cremophor } r h \text { 40/ } \\
\text { transcutol/air }\end{array}$ \\
\hline
\end{tabular}

\section{KESAN NISBAH S/KOS TERHADAP PEMBENTUKAN SISTEM MIKROEMULSI ASID OLEIK/CREMOPHOR RH 40/TRANSCUTOL/AIR}

Bahagian yang berlorek pada gambar rajah fasa adalah mewakili rantau mikroemulsi yang mempunyai larutan yang jernih, stabil tanpa sebarang pemisahan fasa. Manakala, bahagian yang sebaliknya pula mewakili fasa bukan mikroemulsi yang memberikan larutan yang keruh serta berlaku pemisahan fasa selepas 48 jam penambahan air. Penyediaan mikroemulsi dilakukan dengan peningkatan berat air yang diwakili oleh anak panah sebagai garis pencairan air seperti yang ditunjukkan setiap gambar rajah fasa.

Gambar rajah fasa pseudo-ternari bagi sistem mikroemulsi yang terdiri daripada fasa minyak tunggal (M1) iaitu asid oleik, Cremophor rh 40 sebagai surfaktan dan Transcutol sebagai kosurfaktan pada nisbah Km ditunjukkan dalam Rajah 1. Kesesuaian nisbah Km bagi pembentukan sistem mikroemulsi ini boleh disenaraikan mengikut urutan: $\mathrm{Km}=2: 1(25.9 \%)>\mathrm{Km}=1: 1(25.5 \%)>\mathrm{Km}=3: 1$ (20.9\%). Pada nisbah 1:9 (minyak:S/KoS) pembentukan sistem mikroemulsi berlaku dengan kandungan air 0-45 \% bt. (Km 1:1), $0-55 \%$ bt. (Km 2:1) dan 0-40 \% bt. (Km 3:1). Selain itu, pada nisbah $\mathrm{S} / \mathrm{KoS}$ yang rendah, sistem mikroemulsi berupaya terbentuk sehingga $70 \%$ bt. (minyak):30 \% bt. (S/KoS) bagi Km 2:1 dan 1:1, manakala $60 \%$ bt. (minyak): $40 \%$ bt. (S/KoS) bagi Km 3:1. Namun, pada nisbah S/KoS yang rendah, sistem mikroemulsi hanya berupaya terbentuk sehingga $<40 \%$ bt. S/KoS bagi Km 2:1 dan 1:1, manakala $<50 \%$ bt. S/KoS bagi Km 3:1.

Pembentukan mikroemulsi dipengaruhi oleh struktur dan sifat fasa minyak, surfaktan dan kosurfaktan (Agubata et al. 2014; Basheer et al. 2013; Sripriya et al. 2007). Penyelidikan ini menggunakan surfaktan cremophor rh 40 yang merupakan surfaktan tidak bercas, struktur bercabang dan mempunyai rantai panjang pada bahagian ekor. Struktur bercabang molekul cremophor rh 40 mungkin menyukarkan molekul transcutol menyusun di antara lapisan surfaktan dan mengurangkan kestabilan sistem mikroemulsi. Perkara ini dapat dilihat pada Km 1:1 dan 2:1 iaitu pada kandungan cremophor rh 40 yang rendah dan ia berupaya menghasilkan rantau mikroemulsi lebih luas berbanding $\mathrm{Km}=3: 1$. Berbeza daripada struktur cremophor rh 40, transcutol pula berantai lurus dan pendek yang bertindak sebagai kosurfaktan. Bahagian hidrofobik molekul transcutol berupaya menyusun di dalam lapisan cremophor rh 40 sekaligus meningkatkan kebendaliran antara muka, manakala bahagian hidrofilik transcutol akan merendahkan kekutuban air oleh kerana sifatnya yang larut air (Syed \& Peh 2014). Kelebihan struktur kosurfaktan daripada kumpulan ini didapati mampu merendahkan tegangan antara muka minyak-air dan menstabilkan pembentukan sistem mikroemulsi. Kandungan transcutol pada nisbah cremophor rh 40:transcutol pada Km 2:1 menunjukkan nisbah optimum untuk merendahkan

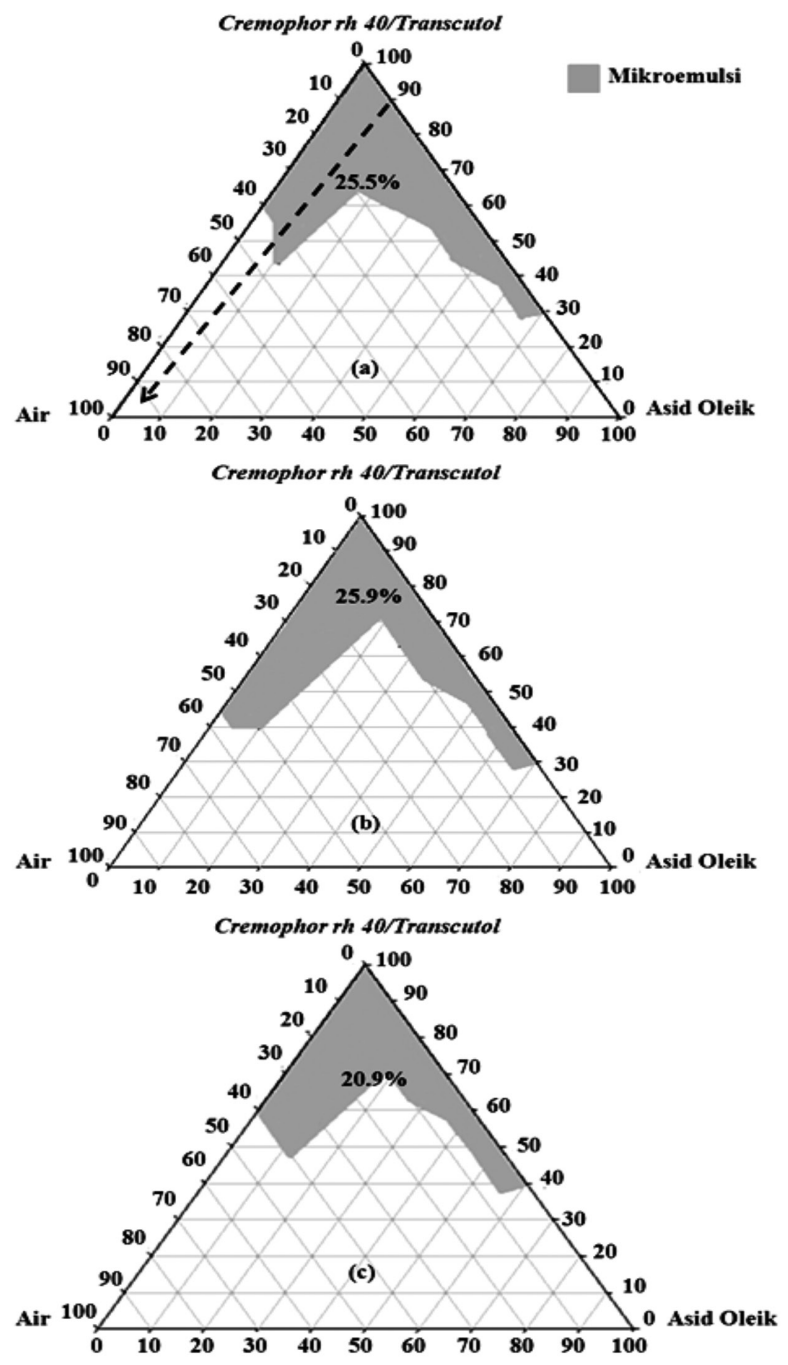

RAJAH 1. Gambar rajah fasa pseudo-ternari bagi sistem asid oleik/cremophor $\mathrm{RH}$ 40/transcutol/air (M1) bagi (a) $\mathrm{Km}=1: 1$, (b) $\mathrm{Km}=2: 1$ and (c) $\mathrm{Km}=3: 1$. Anak panah mewakili garis pencairan air yang menunjukan penambahan kandungan air dengan pengurangan kandungan surfaktan/kosurfaktan dan minyak 
tegangan antara muka fasa minyak-air seterusnya membantu menstabilkan pembentukan mikroemulsi.

\section{KESAN NISBAH LIMONENA/ASID OLEIK TERHADAP} GAMBAR RAJAH FASA SISTEM MIKROEMULSI ASID OLEIK/ CREMOPHOR RH 4O/TRANSCUTOL/AIR

Kesan penambahan limonena sebagai fasa minyak pada sistem mikroemulsi dikaji pada nisbah limonena/asid oleik (L/AO) 1:1, 2:1 dan 3:1. Rajah 2 sehingga Rajah 4 menunjukkan gambar rajah fasa bagi sistem mikroemulsi asid oleik/limonena/cremophor rh 40/transcutol/air (M2) pada nisbah L/AO dan Km yang berbeza. Berdasarkan kepada keluasan rantau pembentukan mikroemulsi, penambahan limonena dijumpai berupaya menghasilkan rantau mikroemulsi lebih besar berbanding sistem tanpa limonena pada garis pencairan air 1:9. Bagi setiap nisbah $\mathrm{Km}$, sistem yang mengandungi limonena berupaya menghasilkan sistem mikroemulsi sehingga 70\%-80\% bt. air berbanding sistem tanpa limonena yang hanya menghasilkan sehingga 45\%-50 \% bt. pada nisbah minyak:S/KoS (1:9). Secara keseluruhnya, penambahan limonena pada nisbah L/AO (1:1) menunjukkan rantau pembentukan mikroemulsi yang terluas pada nisbah $\mathrm{Km}=2: 1$ dan pada nisbah minyak:S/KoS (1:9). Walau bagaimanapun, perbezaan keluasan rantau mikroemulsi yang terbentuk bagi setiap nisbah L/AO adalah tidak terlalu ketara pada setiap nisbah Km iaitu antara 15\%$22 \%$. Kelebihan formulasi mikroemulsi yang terdiri daripada minyak hidrokarbon siklik seperti limonene adalah ia berupaya mempengaruhi agregasi dan struktur penyusunan lapisan surfaktan, sekaligus meningkatkan kestabilan pembentukan sistem mikroemulsi (Fanun 2010, 2007; Sripriya et al. 2007). Hal ini adalah kerana minyak daripada kumpulan ini dilihat berupaya menembusi serta menyusun di antara lapisan molekul surfaktan pada fasa antara muka minyak-air dan memperluaskan keratan rentas per surfaktan, seterusnya menstabilkan pembentukan sistem mikroemulsi (Fanun 2010).

\section{SAIZ PARTIKEL DAN KESTABILAN SISTEM MIKROEMULSI}

Kesan penambahan limonena terhadap sistem mikroemulsi dikaji berdasarkan kepada perubahan purata saiz partikel sistem bagi penambahan air $10 \%$ hingga $50 \%$ bt. air. Perubahan ini ditentukan dengan menggunakan alat penganalisis saiz partikel. Jadual 2 menunjukkan perubahan purata saiz partikel sistem M1 dan M2. Kedua-dua sistem ini memperlihatkan pengurangan nilai purata saiz partikel dengan peningkatan berat air. Selain itu, kehadiran limonena juga dilihat menghasilkan sistem dengan purata saiz partikel yang lebih rendah berbanding sistem tanpa limonena. Kesemua sistem mikroemulsi mempunyai saiz partikel dalam rantau saiz partikel sistem mikroemulsi

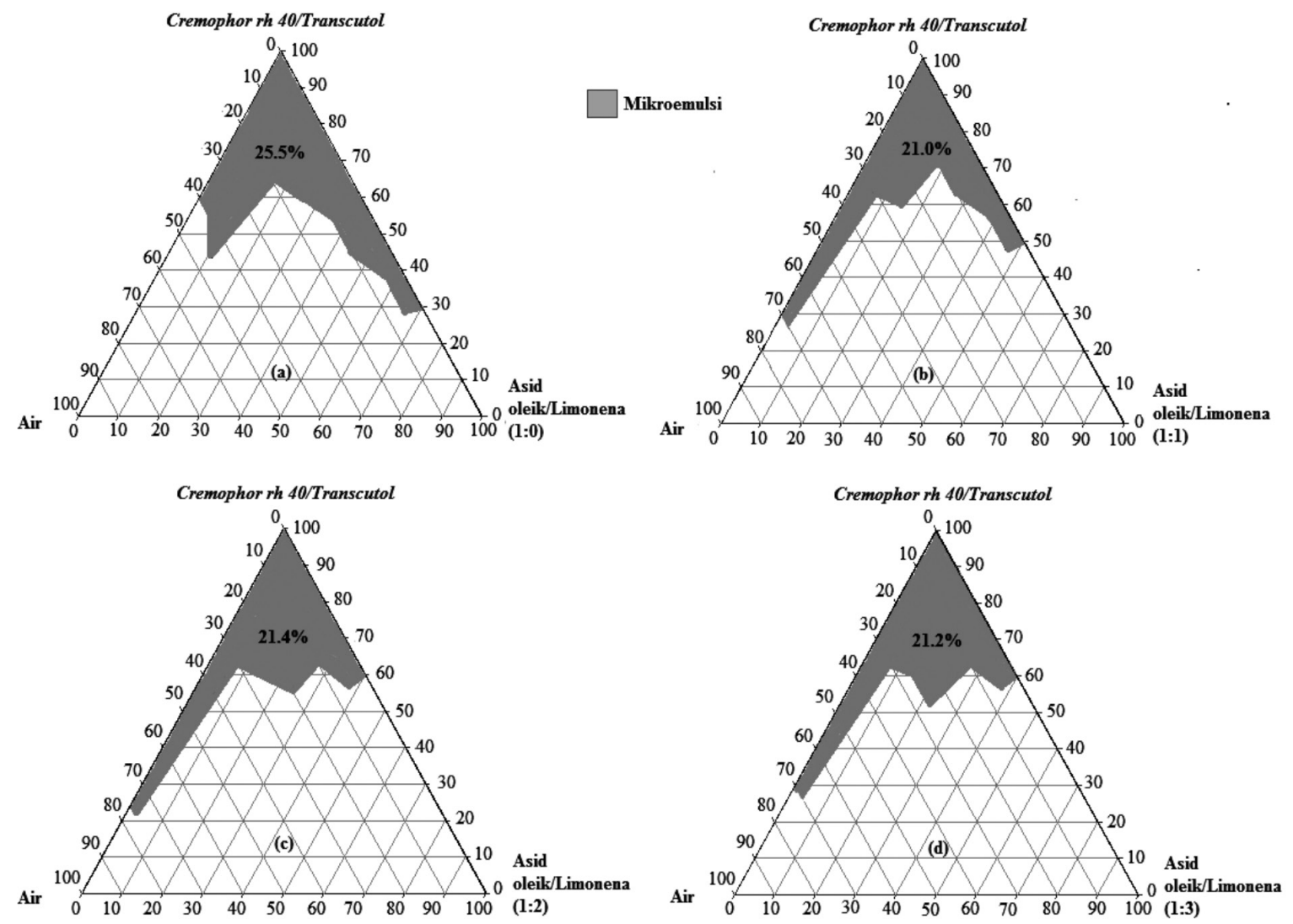

RAJAH 2. Gambar rajah fasa pseudo-ternari sistem mikroemulsi dengan nisbah $\mathrm{Km}=1: 1$ dan asid oleik/limonena (a) 1:0, (b) 1:1, (c) 1:2 dan (d) 1:3 

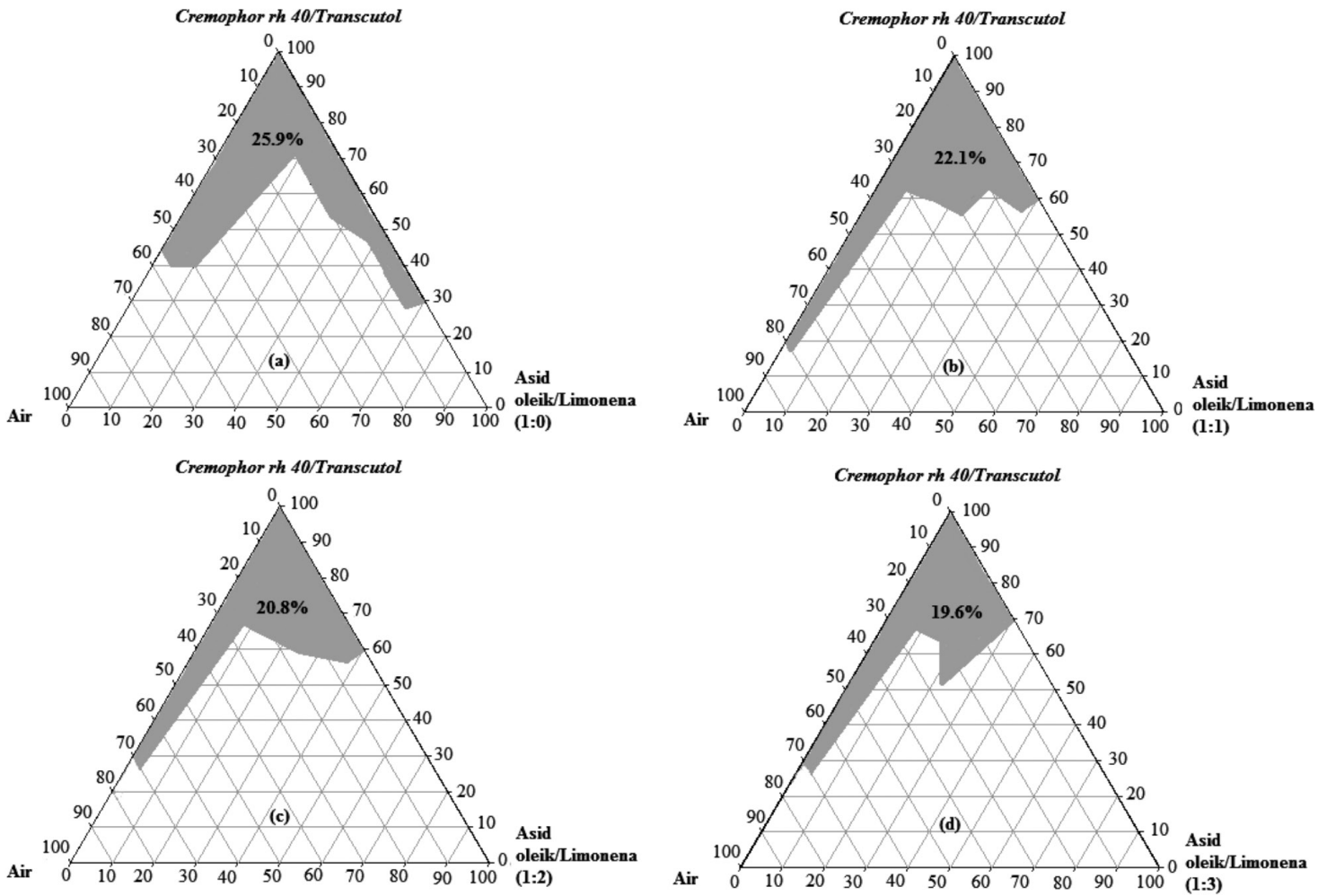

RAJAH 3. Gambar rajah fasa pseudo-ternari sistem mikroemulsi dengan nisbah $\mathrm{Km}=2: 1$ dan asid oleik/limonena (a) 1:0, (b) 1:1, (c) 1:2 dan (d) 1:3
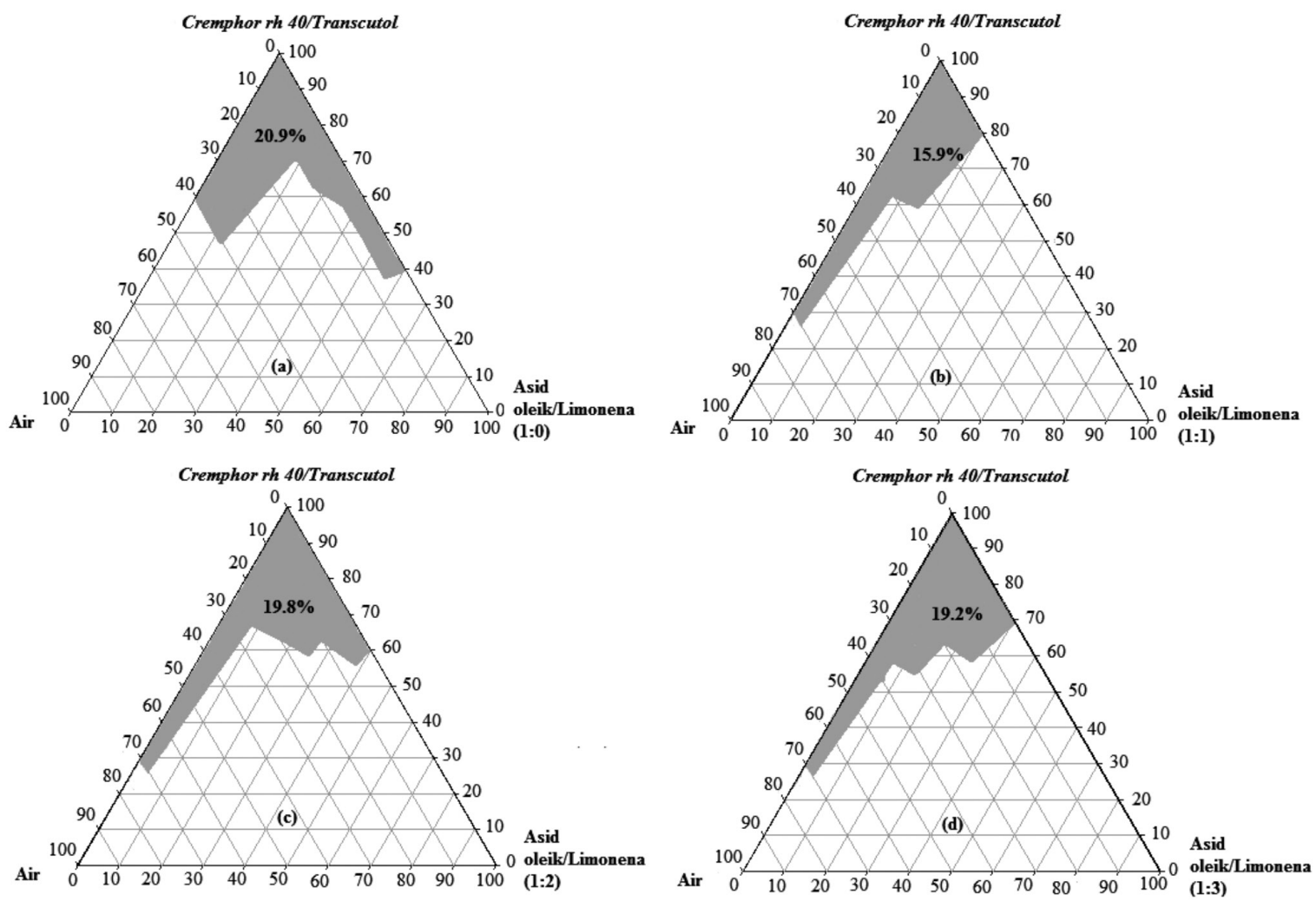

RAJAH 4. Gambar rajah fasa pseudo-ternari sistem mikroemulsi dengan nisbah $\mathrm{Km}=3: 1$ dan asid oleik/limonena (a) 1:0, (b) $1: 1$, (c) $1: 2$ dan (d) $1: 3$ 
JADUAL 2. Purata saiz titisan dan indeks refraktif sistem mikroemulsi

\begin{tabular}{cccc}
\hline Sampel & $\begin{array}{c}\text { Peratusan berat air } \\
(\% \text { bt. })\end{array}$ & $\begin{array}{c}\text { Saiz titisan } \\
(\mathrm{nm})\end{array}$ & Indeks refraktif \\
\hline M1 10\% & 10 & $22.1 \pm 1.5$ & 1.45 \\
M1 20\% & 20 & $33.9 \pm 1.7$ & 1.44 \\
M1 30\% & 30 & $36.8 \pm 0.3$ & 1.43 \\
M1 40\% & 40 & $45.9 \pm 0.1$ & 1.41 \\
M1 50\% & 50 & $52.4 \pm 0.1$ & 1.40 \\
M2 10\% & 10 & $21.0 \pm 0.6$ & 1.44 \\
M2 20\% & 20 & $29.5 \pm 0.4$ & 1.43 \\
M2 30\% & 30 & $33.9 \pm 0.2$ & 1.42 \\
M2 40\% & 40 & $38.8 \pm 0.1$ & 1.41 \\
M2 50\% & 50 & $41.5 \pm 0.0$ & 1.40 \\
\hline
\end{tabular}

$(<100 \mathrm{~nm})$ (Talegaonkar et al. 2008). Penentuan saiz partikel sistem juga secara tidak langsung berupaya menggambarkan pembentukan jenis mikroemulsi seperti air-dalam-minyak, minyak-dalam-air atau dwiselanjar yang terhasil pada komposisi air yang tertentu. Sistem dengan saiz partikel yang lebih besar boleh dikategorikan sebagai mikroemulsi jenis air-dalam-minyak, yang seterusnya menunjukkan pengurangan purata saiz partikel disebabkan oleh perubahan daripada mikroemulsi jenis air-dalam-minyak kepada dwiselanjar dan minyak-dalamair (Basheer et al. 2013). Hasil kajian mendapati bahawa penambahan limonena tidak menyebabkan perubahan fasa ataupun struktur system. Perkara ini diterangkan berdasarkan kepada sifat konduktiviti dan kelikatan sistem yang dibincang pada bahagian seterusnya. Di samping itu, Jadual 2 turut menunjukkan indeks refraktif (RI) bagi sistem M1 dan M2. Nilai RI juga digunakan sebagai penentuan awal di dalam menentukan jenis sistem mikroemulsi yang terhasil dan nilai tersebut menurun dengan meningkatnya berat kandungan air (Basheer et al. 2013). Sebagai contoh, mikroemulsi jenis air-dalam-minyak (sampel M1 10\% dan 20\% serta M2 10\% dan 20\%) mempunyai nilai indeks refraktif yang lebih tinggi berbanding mikroemulsi jenis dwiselanjar bagi kedua-dua sistem.

Kestabilan sistem mikroemulsi dilakukan pada suhu rendah $\left(4^{\circ} \mathrm{C}\right)$, suhu bilik $\left(25^{\circ} \mathrm{C}\right)$ dan suhu tinggi $\left(37^{\circ} \mathrm{C}\right)$ selama sebulan. Hasil pemerhatian menunjukkan kesemua sistem kekal stabil tanpa sebarang pemisahan fasa dan agregasi partikel pada setiap suhu penyimpanan bagi tempoh sebulan.

\section{KONDUKTIVITI DAN KELIKATAN SISTEM MIKROEMULSI}

Kajian terhadap pembentukan dan perubahan fasa-fasa mikroemulsi daripada air-dalam-minyak $(\mathrm{a} / \mathrm{m})$ kepada minyak-dalam-air (m/a) melalui fasa dwiselanjar (bc) adalah sangat penting bagi penyelidikan sistem mikroemulsi. Dalam penyelidikan ini, pengukuran nilai konduktiviti dan kelikatan sistem mikroemulsi digunakan untuk melihat perubahan fasa dan struktur sistem mikroemulsi yang terbentuk. Rajah 5(a) menunjukkan konduktiviti elektrik (KE) bagi sistem mikroemulsi M1 dan M2. Umumnya, sistem mikroemulsi yang terdiri daripada minyak/surfaktan/air mempamerkan fenomena ambang perkolasi berdasarkan profil KE (Fanun 2009). Fenomena ini menunjukkan peningkatan yang perlahan dengan peningkatan kandungan air, seterusnya meningkat secara mendadak pada kepekatan genting air dan kembali kepada perubahan yang perlahan pada kandungan air yang tinggi (Fanun 2009; Suria et al. 2015, 2009). Sistem mikroemulsi M1 dan M2 masing-masing memberikan nilai KE yang rendah dan peningkatan yang perlahan pada $10 \%$ hingga $20 \%$ bt. air, manakala meningkat secara mendadak pada 30 hingga $50 \%$ bt. air. Nilai KE yang rendah dan perubahan yang perlahan pada kandungan $<30 \%$ bt. air adalah merujuk kepada pembentukan mikroemulsi jenis a/m. Ia berpunca daripada pergerakan molekul air yang terhad serta partikel air yang terpisah di dalam fasa selanjar minyak menjadikan interaksi antara molekul air adalah lemah (Metha \& Kaur 2011; Suria et al. 2009). Peningkatan KE yang berlaku secara mendadak pada 30 hingga $50 \%$ bt. air pula menggambarkan interaksi di antara fasa akueus yang semakin kuat dan mula membentuk jaringan konduktif mikroemulsi fasa dwiselanjar. Keseluruhannya, penyelidikan ini hanya menunjukkan perubahan fasa mikroemulsi daripada a/m (10-20 \% bt. air) kepada bc (30-50 \% bt. air).

Rajah 5(b) menunjukkan perubahan nilai kelikatan bagi sistem M1 dan M2 pada suhu $25^{\circ} \mathrm{C}$ dengan peningkatan kandungan air di dalam sistem. Perubahan kelikatan sistem mikroemulsi juga berupaya memberi gambaran kepada perubahan mikrostruktur sistem yang terdiri daripada pembentukan fasa tersebar kepada struktur dwiselanjar yang saling bersambung (Paul \& Moulik 2000). Kedua-dua sistem M1 dan M2 menunjukkan perubahan kelikatan yang kecil pada $<30 \%$ bt. air. Perubahan yang kecil bagi sistem dengan kandungan air $<30 \%$ bt. mencadangkan pembentukan mikroemulsi jenis $\mathrm{a} / \mathrm{m}$ (air tersebar di dalam fasa penyebar minyak). Ia didorong oleh peningkatan kandungan air di dalam sistem dan juga merujuk kepada perubahan struktur fasa mikroemulsi daripada bentuk sfera kepada asimmetrik (Suria et al. 2009). Seterusnya, boleh dilihat peningkatan kelikatan yang berlaku secara mendadak pada $30 \%$ bt. air dan mencapai nilai maksimum pada $40 \%$ bt. air, 

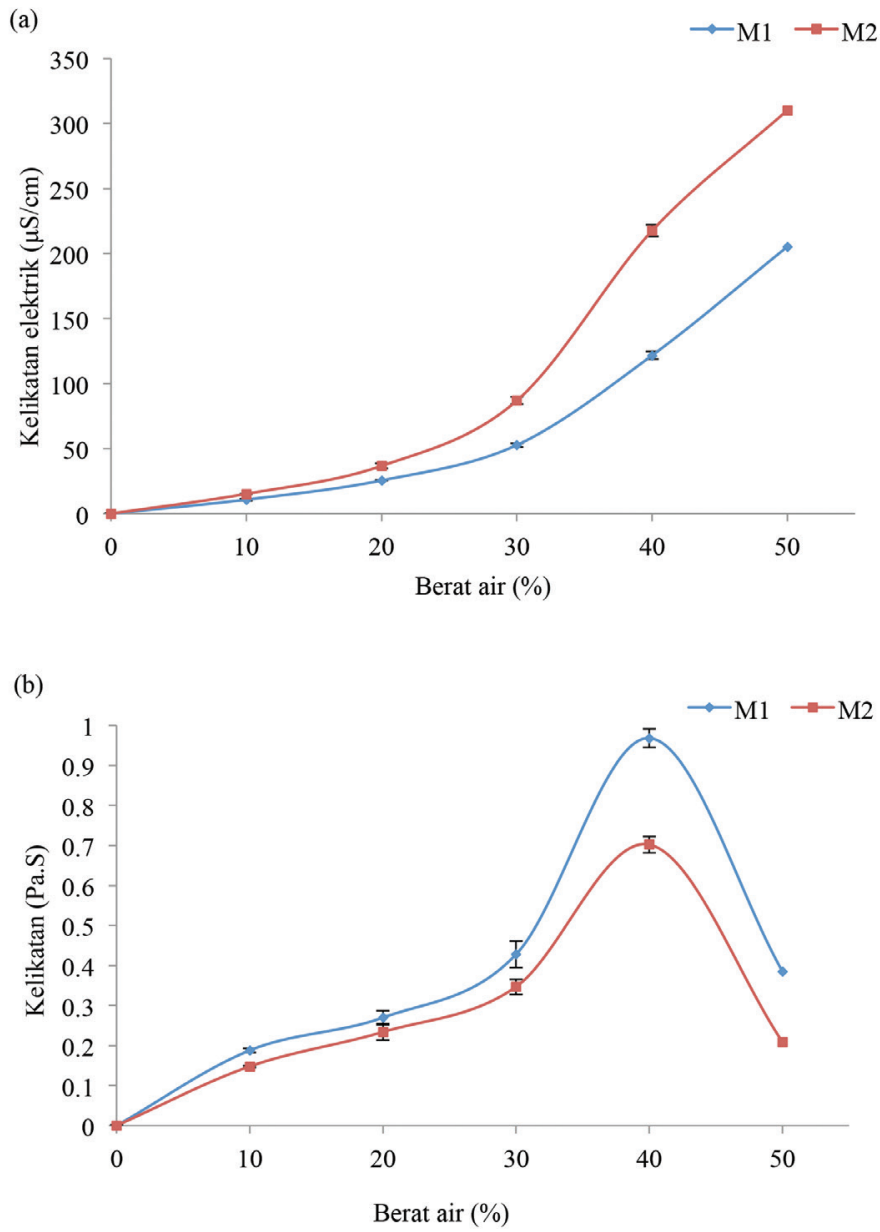

RAJAH 5. Profil (a) Konduktiviti elektrik dan (b) Kelikatan sistem M1 (Asid oleik/cremophor rh 40/transcutol/air) dan M2 (Asid oleik/limonena/cremophor rh 40/transcutol/air)

sebelum ia menurun semula pada kandungan air yang lebih tinggi (50\% bt. air). Perubahan yang ketara bagi nilai kelikatan sistem mikroemulsi adalah didorong oleh perubahan struktur sistem umumnya daripada fasa $\mathrm{a} / \mathrm{m}$ kepada bc, kemudiaannya kepada fasa m/a (Moulik \& Rakshit 2006; Paul \& Moulik 2000). Pada kandungan 40 $\%$ bt. air, kelikatan bagi kedua-dua sistem mencapai nilai maksimum dan ia menerangkan bahawa pembentukan fasa dwiselanjar telah berlaku dengan lengkap. Penurunan yang drastik bagi $>40$ hingga $50 \%$ bt. pula mencadangkan perubahan daripada fasa dwiselanjar kepada m/a. Jika melihat kepada kesan penambahan limonena terhadap sifat konduktiviti dan kelikatan sistem mikroemulsi, ia hanya memperlihatkan perubahan terhadap nilai konduktiviti dan kelikatan sistem tanpa merubah fasa keseluruhan sistem.

\section{KESIMPULAN}

Nisbah optimum bagi surfaktan/kosurfaktan dan limonena/ asid oleik bagi pembentukan sistem mikroemulsi asid oleik/limonena/Cremophor rh 40/Transcutol/air adalah masing-masing pada $\mathrm{Km}=2: 1$ dan $\mathrm{L} / \mathrm{AO}=1: 1$.
Penambahan limonena sebagai fasa minyak tidak menunjukkan perubahan yang ketara terhadap fasa serta struktur internal dan juga kestabilan sistem. Kehadiran limonena turut menunjukkan peningkatan pembentukan sistem mikroemulsi sehingga $80 \%$ bt. air. Pengukuran nilai konduktiviti dan kelikatan sistem mencadangkan pembentukan mikroemulsi jenis air-dalam-minyak pada 10-20 \% bt. air dan dwiselanjar pada 30-50\% bt. air. Kestabilan sistem yang tinggi membuktikan potensi sistem tersebut sebagai sistem penghantar bahan aktif yang tidak akan dipengaruhi oleh suhu penyimpanan. Hasil kajian ini turut menunjukkan bahawa sistem mikroemulsi berasaskan-asid oleik mahupun-asid oleik/ limonena berpotensi sebagai sistem penghantar bahan aktif.

\section{PENGHARGAAN}

Penulis ingin mengucapkan ribuan terima kasih kepada Universiti Kebangsaan Malaysia dan Kementerian Pelajaran Malaysia atas tajaan yang telah diberikan di bawah geran penyelidikan GGP-2017-087 dan FRGS-12013-SG01-UKM03-1. 


\section{RUJUKAN}

Agubata, C.O., Nzekwe, I.T., Obitte, N.C., Ugwu, C.E., Attama, A.A. \& Onunkwo, G. C. 2014. Effect of oil, surfactant and co-surfactant concentrations on the phase behavior, physicochemical properties and drug release from selfemulsifying drug delivery systems. Journal of Drug Discovery, Development and Delivery 1(1): 1-7.

Al Abood, R.M., Talegaonkar, S., Tariq, M. \& Ahmad, F.J. 2013. Microemulsion as a tool for the transdermal delivery of ondansetron for the treatment of chemotherapy induced nausea and vomiting. Colloids and Surfaces B: Biointerfaces 101: 143-151.

Anjana, D., Nair, K.A. \& Somashekara, N. 2012. Development of curcumin based ophthalmic formulation. American Journal of Infectious Diseases 8(1): 41-49.

Basheer, H.S., Mohamed, I.N. \& Mowafaq, M.G. 2013. Characterization of microemulsions prepared using isopropyl palmitate with various surfactants and cosurfactants. Tropical Journal of Pharmaceutical Research 12(3): 305310.

Fanun, M. 2012. Microemulsions as delivery systems. Current Opinion in Colloid \& Interface Science 17: 306-313.

Fanun, M. 2010. Microemulsions with nonionic surfactants and mint oil. The Open Colloid Science Journal 3: 9-14.

Fanun, M. 2008. Microemulsions: Properties and applications. Boca Raton: CRC Press. pp. 101-108.

Fanun, M. 2007. Phase behavior, structure evolution and diclofenac solubilization studies on mixed nonionic surfactants microemulsions. In Non-Ionic Surfactants, edited by Wendt, P.L. \& Hoysted, D.S. New York: Nova Science Publishers. pp. 245-284.

Grampurohit, N.D., Ravikumar, P. \& Mallya, R. 2011. Microemulsion for topical use-a review. Indian Journal of Pharmaceutical Education and Research 45(1): 100-107.

Idress, M.A., Rahman, N.U., Ahmad, S., Ali, M.Y. \& Ahmad, I. 2011. Enhance transdermal delivery of flurbiprofen via microemulsions: Effects of different types of surfactants and cosurfactants. DARU 19(6): 433-438.

Liu, C.H., Chang, F.Y. \& Hung, D.K. 2011. Terpene microemulsions for transdermal curcumin delivery: Effects of terpenes and cosurfactants. Colloids and Surfaces B: Biointrefaces 82: 63-70.

Maura, P., Bragagni, M., Menini, N., Cirri, M. \& Maestrelli, F. 2014. Development of liposomal and microemulsion formulations for transdermal delivery of clonazepam: Effect of randomly methylated $\beta$-cyclodextrin. International Journal of Pharmaceutics 475(1-2): 306-314.

Metha, S.K. \& Kaur, G. 2011. Microemulsions: Thermodynamic and dynamic properties. In Thermodynamics, edited by Mizutani Tadashi. London: InTech. pp. 381-406.

Moulik, S.P. \& Rakshit, A.K. 2006. Physicochemistry and applications of microemulsions. Journal of Surface Science and Technology 22(3-4): 159-186.

Patel, R.B., Patel, M.R., Bhatt, K.K. \& Patel, B.G. 2013. Formulation and evaluation of microemulsions-based drug delivery system for intranasal administration of olanzapine. International Journal of Biomedical and Pharmaceutical Sciences 7(1): 20-27.

Paul, B.K. \& Moulik, S.P. 2000. The viscosity behaviours of microemulsions: An overview. PINSA 66(5): 499-519.

Sarkar, K.B. \& Hardenia, S.S. 2011. Microemulsion drug delivery system: For oral bioavailability enhancement of glipizide. Journal of Advanced Pharmacy Education \& Research 1(4): 195-200.
Shahzadi, I., Masood, M.I., Chowdhary, F., Anjum,A.A., Nawaz, M.A., Maqsood, I. \& Zaman, M.Q. 2014. Microemulsion formulation for topical delivery of miconazole nitrate. International Journal of Pharmaceutical Sciences Review and Research 24(2): 30-36.

Silva, A.E., Barrat, G., Cheron, M. \& Egito, E.S.T. 2013. Development of oil-in-water microemulsions for the oral delivery of amphotericin B. International Journal of Pharmaceutics 454(2): 641-648.

Singh, A. \& Vijaykumar, M. 2013. The effect of penetration enhancers on the permeation of sulfonyl urea derivative. Der Pharmacia Lettre 5(6): 171-175.

Singla, V., Saini, S., Singh, G., Rana, A.C. \& Joshi, B. 2011. Penetration enhnacers: A novel strategy for enhancing transdermal drug delivery. International Research Journal of Pharmacy 2(12): 32-36.

Sintov, A.C. 2015. Transdermal delivery of curcumin via microemulsion. International Journal of Pharmaceutics 481: 97-103

Som, I., Bhatia, K. \& Yasir, M. 2012. Status of surfactants as penetration enhancers in transdermal drug delivery. Journal of Pharmacy and Bioallied Sciences 4(1): 2-9.

Sripriya, R., Raja, M.K., Santhosh, G., Chandrasekhara, N. \& Noel, M. 2007. The effect of structure of oil phase, surfactant and co-surfactant on the physicochemical and electrochemical properties of bicontinuous microemulsion. Journal of Colloid and Interface Science 314: 712-717.

Suria, R., Safiah, M.J., Muhd Asri, A.S., Norhidayu, Z. \& Irman, A.R. 2015. Formulation and physical characterization of microemulsion based carboxymethyl cellulose as vitamin c carrier. Malaysian Journal of Analytical Sciences 19(1): 275-283.

Suria, R., Benjamin, P.R. \& Ian, R.G. 2009. Formulation and physical characterization of microemulsions containing isotretinoin. International Conference on Biomedical and Pharmaceutical Engineering. pp. 1-7.

Syed, H.K. \& Peh, K.K. 2014. Identification of phases of various oil, surfactant/co-surfactants and water system by ternary phase diagram. Acta Poloniac Pharmaceutica-Drug Research 71(2): 301-309.

Talegaonkar, S., Adnan, A., Farhan, J.A., Roop, K.K., Shadab, A. \& Zeenat, I.K. 2008. Microemulsions: A novel approach to enhanced drug delivery. Recent Patents Drug Delivery \& Formulation 2(3): 238-257.

Williams, A.C. \& Barry, B.W. 2004. Penetration enhancers. Advanced Drug Delivery Reviews 56(5): 603-618.

Zainuddin, N., Ahmad, I. \& Ramli, S.*

Pusat Pengajian Sains Kimia dan Teknologi Makanan

Fakulti Sains dan Teknologi

Universiti Kebangsaan Malaysia

43600 UKM Bangi, Selangor Darul Ehsan

Malaysia

Ahmad, I. \& Ramli, S.*

Pusat Penyelidikan Polimer (PORCE)

Fakulti Sains dan Teknologi

Universiti Kebangsaan Malaysia

43600 UKM Bangi, Selangor Darul Ehsan

Malaysia

Abdul Rahman, I.

Pusat Pengajian Fizik Gunaan 
Fakulti Sains dan Teknologi Universiti Kebangsaan Malaysia 43600 UKM Bangi, Selangor Darul Ehsan Malaysia

*Pengarang untuk surat-menyurat; email: su_ramli@ukm. edu.my
Diserahkan: 24 Januari 2017

Diterima: 10 Ogos 2017 